\title{
Impact of Globalization On Education and Gender in The Democratic Republic of Congo
}

\author{
Sifa Bura Huguette \\ Economics and Management of Education, Central China Normal University, Wuhan, China \\ Hubei, Wuhan, Hongshan \\ E-mail: huguettesifa@yahoo.com
}

\begin{tabular}{l} 
Article Info \\
\hline Received Januari 2021 \\
Accepted April 2021 \\
Published April 2021 \\
\hline
\end{tabular}

Keywords:

Globalization, Education, Gender.

\begin{abstract}
Seen as a bittersweet gift to the world today, especially in developing countries, globalization has had both positive and negative impacts on Africans, and especially on the people of the Democratic Republic of Congo. Social, political and economic development are the first sectors of the country' structural changes most affected by the latter in several aspects. Despite the resources of Congo have played an important role in globalization around the world; more so in the world outside Congo. Through the death of millions of people, socioeconomic and psychological challenges, the Congolese people have had to pay a very high price simply to sustain globalization. While expected to help address these challenges, education and gender in the Congo have struggled to face the repeated challenges of globalization effects. This study aims to explore how globalization affects the quality of education and gender when a country is constantly under the challenges of war, political and economic crises, and what is being done about it. Qualitative analysis and documentary research method have been used for data collection and desk review. Adjustment programs suggested by external have showed that the globalization has affected women and men development differentially, with a larger costs assumed by women. Yet girls still suffer significant deprivations and inequalities, many of which result from the persistent gender discrimination faced by girls and women everywhere. To cope with this, reform measures continue to be adopted with a view to economic recovery, with special focus on open education for all by improving access, equality and equity, job creation and reducing poverty in order to improve the living conditions of each.
\end{abstract}

C2021 Jurusan Ilmu Pendidikan, FKIP Universitas Lampung 


\section{INTRODUCTION}

Providing universal compulsory education has long been a goal pursued by all countries as a basic philosophy. This goal received a new direction through the global vision that evolved during the World Conference on Education for All, held in Jomtien (Thailand) in 1990. It was stated: "The most urgent priority is to ensure access to, and improve the quality of education for girls and women, and to remove every obstacle that hampers their active participation. All gender stereotyping in education should be eliminated." It was further emphasized that education programs for women and girls should be designed to eliminate the social and cultural barriers that have excluded them from the benefits of regular education programs, as well as to promote equal opportunities in all aspects of their lives.

In the Democratic Republic of Congo, gender education, especially for girls, had been extensively documented as the investment that offered the greatest overall returns for economic development, national policies did not reflect this insight. It is in view of such an assessment that the Dakar Declaration on Education for All (EFA), as well as the Millennium Declaration, called upon national governments and the international community to pursue more focused action and set concrete targets and a time frame for achieving the goal of gender equality in education.

According to the United Nations in charge of Girls' Education Initiative (UNGEI), the phenomenon of Education for all has been a part of the response to this call at both the international level and national level. Congolese government has also been initiating some action plans to meet the goals of universal participation of girls in education and moving forward to achieve gender equality at all levels of education and in all spheres of life.

What progress has been made in this regard in the Democratic Republic of Congo? Does the progress also meet concerns of quality and equity? Do the overall figures represent real progress towards the goal of gender equality? Are there specific pockets and clusters within the country that continue to lag? These are critical questions that need closer examination. Various assessments indicate substantial progress in gender education; the lives of girls today are better in many respects than those of preceding generations. Girls are now more 
likely to survive childhood, more likely to attend school and complete their education, less likely to be undernourished and less likely to marry as children. But there are significant unevenness across the entire country; they also point to persisting gender and social inequities and serious shortfalls in the quality of provisions and outcomes. There is increasing awareness that actions must move to a different plane from merely counting the number of children enrolled to ensuring that all children enjoy an equal quality of education without gender, ethnic, caste or class distinctions.

This study attempts to take stock of the progress made with respect to some of these questions in the case of the Democratic Republic of Congo. It ends with a summary of the persisting challenges that remain to be addressed, suggesting lessons derived from successful good practice.

\section{Overview on Gender and Education in the Democratic Republic of Congo}

Gender equality is important both for individual people and economic development (Klasen and Lamanna, 2009). Looking at data on gender equality in welfare and work life it is visible that there still are gaps between women and men. At the same time the world we live in is becoming more globalized. Moreover, globalization is often viewed as having both positive and negative impacts, making some people winners while others become losers (Bussmann, 2009).

In this current analysis, the study has looked at the relationship between globalization and gender equality in welfare and work life in the Democratic Republic of Congo. Globalization is complex, affecting information flow, spread of technology, social and political norms as well as economic interactions. Increased globalization, meaning that civilizations become more integrated, might also affect the way people live and behave in a society.

Considering the different aspects of globalization, it is reasonable that it might affect the way of gender equality in DRC. The effect of globalization is trying to answer whether globalization increases or decreases gender equality.

\section{Education system in the Democratic Republic of Congo}

A sound education sector, one of the main sectors of the Government national policies (education, health, infrastructure, social and energy), is 
fundamental for the economic, social, and political transformation of the Democratic Republic of Congo (DRC). The initial purpose was to instruct indigenous people so that they could read and write in the language of the administrative authority as well as advance religious education. Literature and languages present for students a chance to learn more about not only their own, but also that of other culture ideas and values. Development of student's skills in this direction ensures students success not only in school, but also after graduation (MEPS-INC, 2015).

However, the delivery of education services at all levels such as: public, private, conventional and non-conventional levels has not to operate in vacuum. Their institutional performance is generally impacted by the governance context. Several studies and researches conducted on this subject have shown over time that the Congolese education system remains almost underdeveloped because of its low coverage and poor quality, including poor infrastructure, underdeveloped regulatory environment, poverty and bitter misery, parents lack means to support their child education (especially for girls), low productivity of the family workforce in the case of substance farming, no social protection policy, and so on.

\section{METHODOLOGY}

\section{Research Design}

To analyze this concern, the study particularly focused on the qualitative research method, which takes more influence in processes of data collection and analysis. It elaborates the design of the theoretical model of data analysis. The construction of this model will allow us to describe the variables selected in the analyses of secondary data collected in the different consulted reports and documents.

\section{Data collection, Data Management and Instruments}

This qualitative study used three methods of research: Documentary research for the collection of secondary data and archives housed in national reports. The Analytical method for a discriminatory analysis of the data collected and the provisions relating to the above mentioned problems. The 
descriptive method will facilitate the inventory of items collected during the above mentioned period. These three methods have been supported by the technique of documentary analysis for access to the various sources of information and the necessary data and its analyses to the elaboration of this work.

\section{Theoretical model analysis}

The theoretical analysis of the impact of globalization on gender and education in the Democratic Republic of the Congo during modernization and globalization period; the overview on gender and education in the DRC and its analyses; the theoretical view on DRC education sector goals and its priorities allow the study to build the theoretical model (figure 1). Indeed, taking into account two main variables of our study (dependent and independent variables, including globalization and gender education), the study proposed a theoretical model adapted to these two variables. This model is used to analyze the impact of globalization as a tools and strategies of the improvement of quality in the DRC' gender education access and also to the data available to meet the concerns of the study.

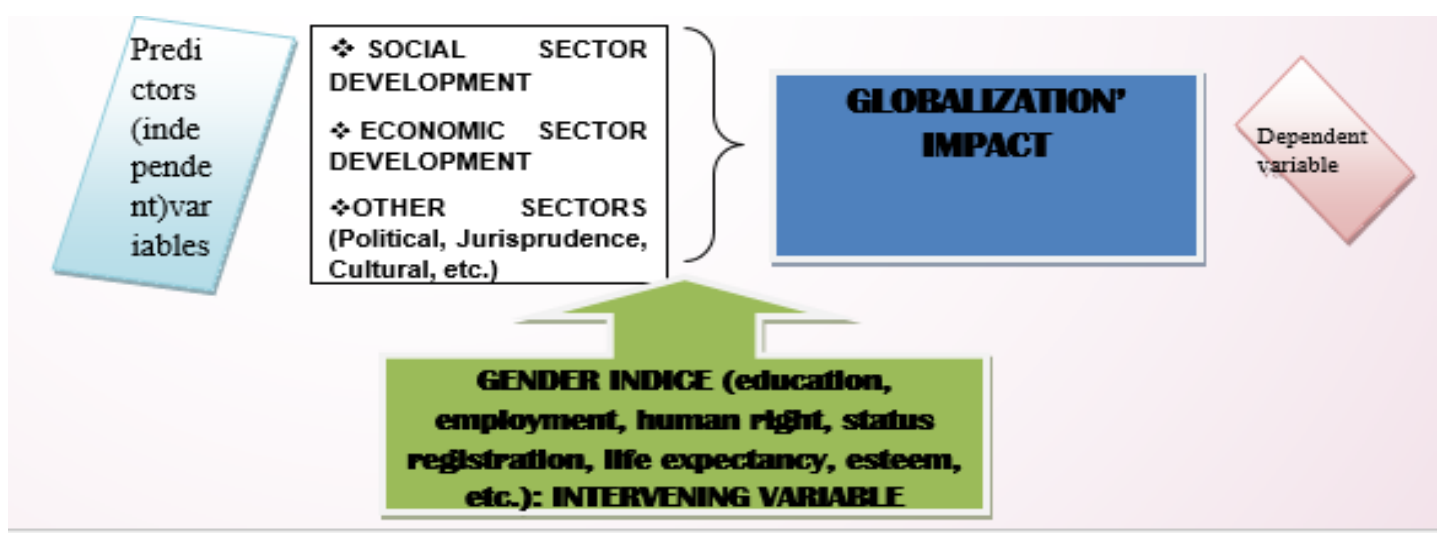

Source : Author' conception, 2018

Figure 1. Relationship between variables

As we all see above, globalization has had radically changed the world, both positively and negatively, in several aspects. Its impact is having a visible effect on social and economic development, which are directly linked with gender indicator in all levels of countries' structural changes. Adjustment programs suggested by on the economic and political crises have showed that the 
globalization has affected women and men development differentially, with a larger costs assumed by women. Despite some improvement in women' lives, they are still faced with discrimination and inequalities at different society' levels.

\section{RESULT}

\section{Structure of education sector}

The education system structure of schools is composed of four major level such as: kindergartner (pre-primary), primary, secondary (lower and upper) and higher education levels. All these educational levels are administered by three ministries responsible of education, such as: (i) Ministry of primary, secondary and vocational education (MEPS-INC or MPSPE); (ii) Ministry of higher education "MESU" (and scientific research); (iii) Ministry of business humanitarian action and national solidarity/social affairs "MAS" (non-formal education, literacy, remedial classes, technical training as well as adult education).

\section{Official school ages by level of education}
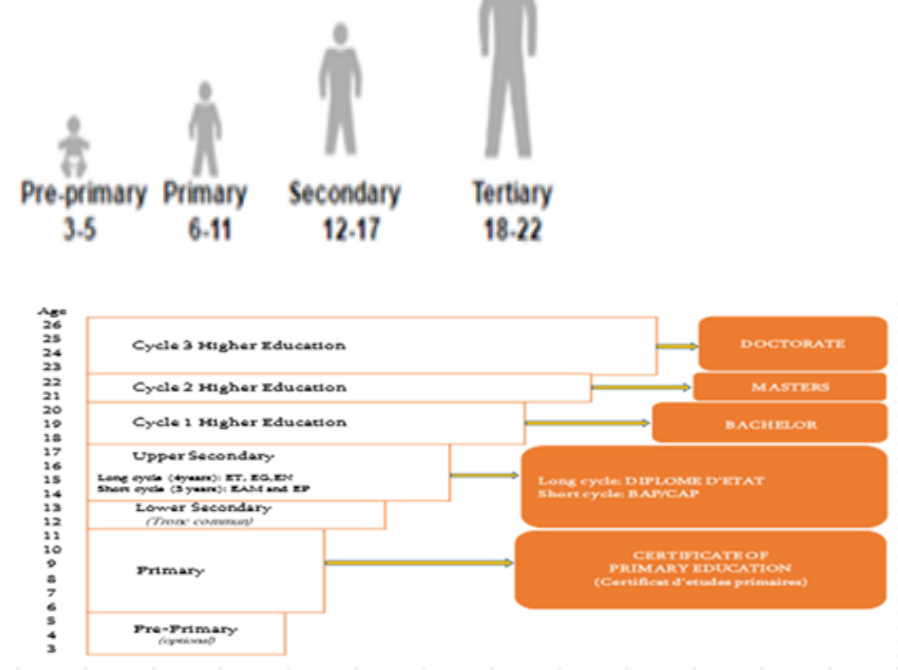

Source: Stratégie Sectorielle 2016-2025

BAP/CAP : Brevet d'aptitude professionnelle/ Certificat d'aptitude professionnelle

EAM : École des Arts et Métiers; EG : École Générale; EN : École Normale; EP: École Professionnelle; ET : École Technique.

Note: This illustration represents the Bachelor, Master, Doctorate (BMD) system that is in the process of implementation

at the time of this report

Source: Author' conception, 2018

Figure 2. Official school ages by level of education 
Note: This traditional education system was reformed in 2014 and we adopted the new framework law signed in Italian city by 30 member countries that use European Higher Education Area to harmonize the standards and quality of higher education across member states. This reform shortens the first and second cycles of higher education to more efficient durations: 3 years (Bachelor degree), 2 years $($ Master degree) $=$ after completion this 2 years undergraduate students can join the labor market earlier than before and 3 to 4 years for Doctorate. This is what we are calling nowadays BMD (BachelorMaster-Doctorate) system.

\section{Gender participation in Education}

\section{Pre-primary education}

It consists of developing early childhood: basic psychomotor and learning skills, using the local language medium. Despite low participation, pre-primary education is an important part of the sector plan to increase enrollment, improve on-time entry, and increase readiness of the children to fully participate in the primary cycle.

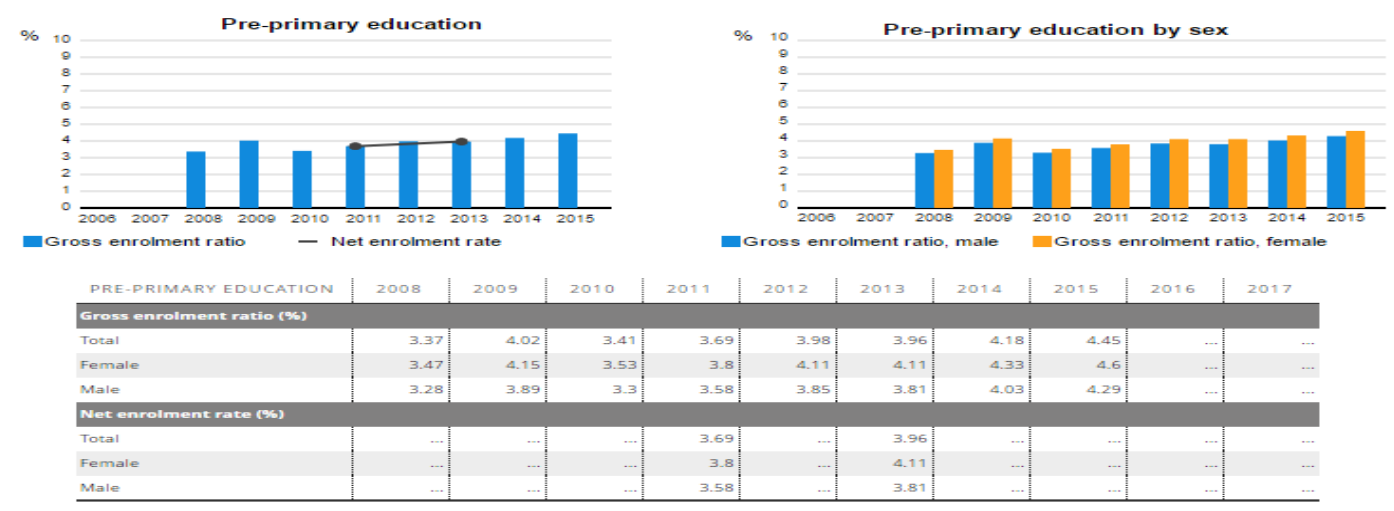

Source: Data from UNESCO Report, 2018

Figure 3. Gross enrollment in pre-primary education

\section{Primary education}

It provides children with basic reading, writing and calculations (mathematics) skills along with an elementary understanding of such subjects as history, geography, natural science, social science, art and music, etc. For example in DRC, schooling officially begins with primary education cycle. 


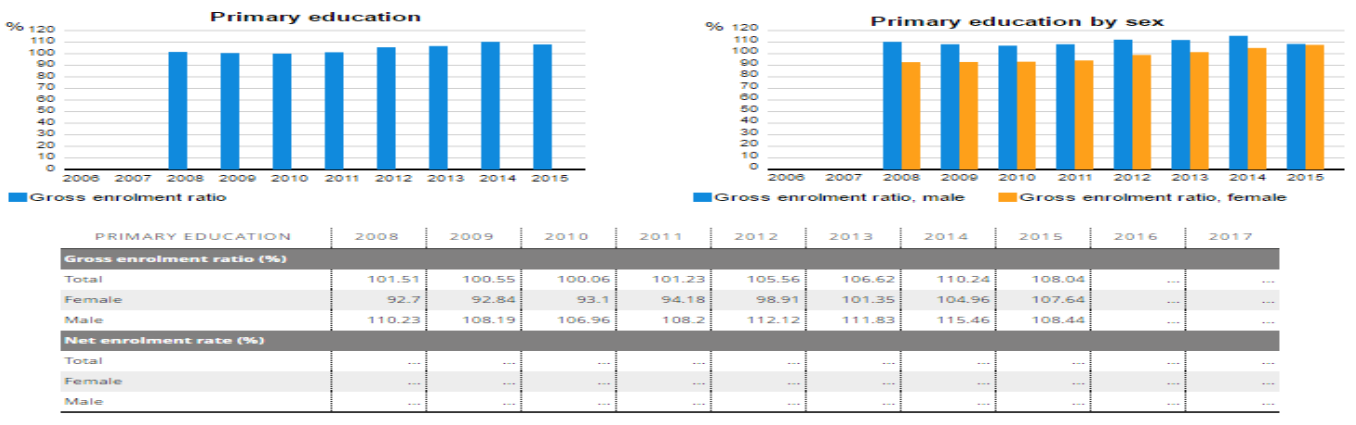

Source: Data from UNESCO Report, 2018

Figure 4. Gross enrollment in primary education

\section{Secondary education}

It completes the provision of basic education that began at the primary level and aims at laying the foundations for lifelong learning and human development by offering more subject or skill-oriented instruction using more specialized teachers.

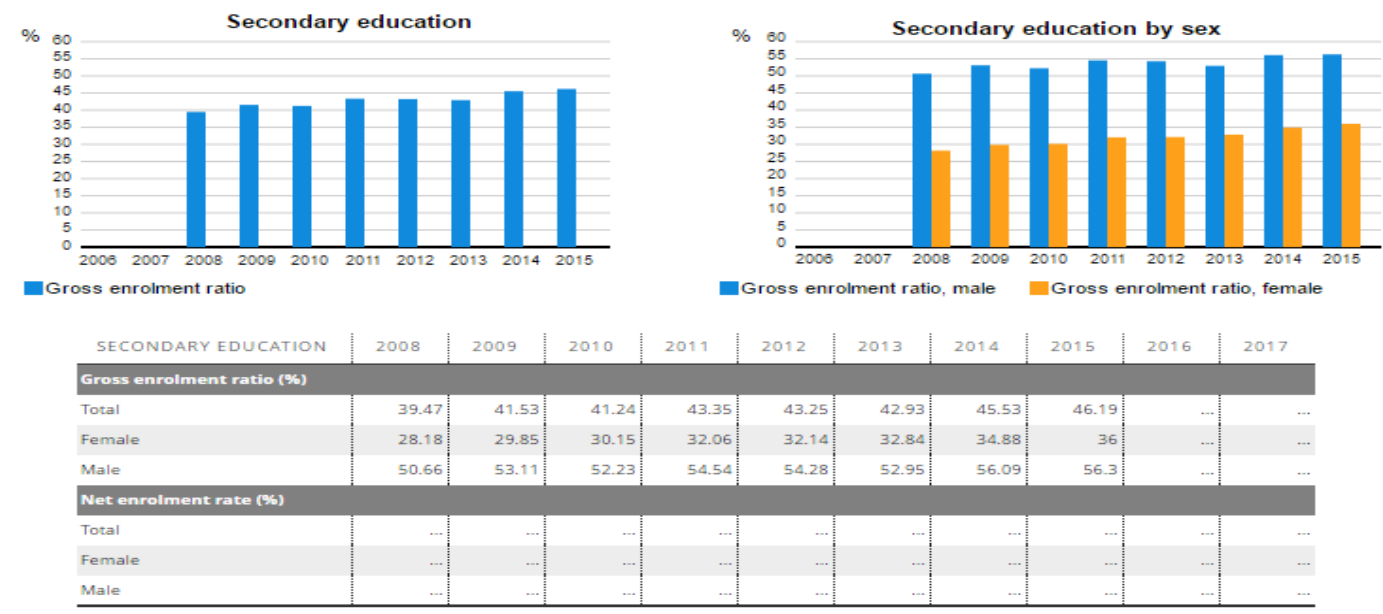

Source: Data from UNESCO Report, 2018

Figure 5. Gross enrollment in secondary education

\section{Tertiary education/Higher education}

Whether or not to an advanced research qualification, normally requires, as a minimum condition of admission, the successful completion of education at the secondary at the secondary level. 


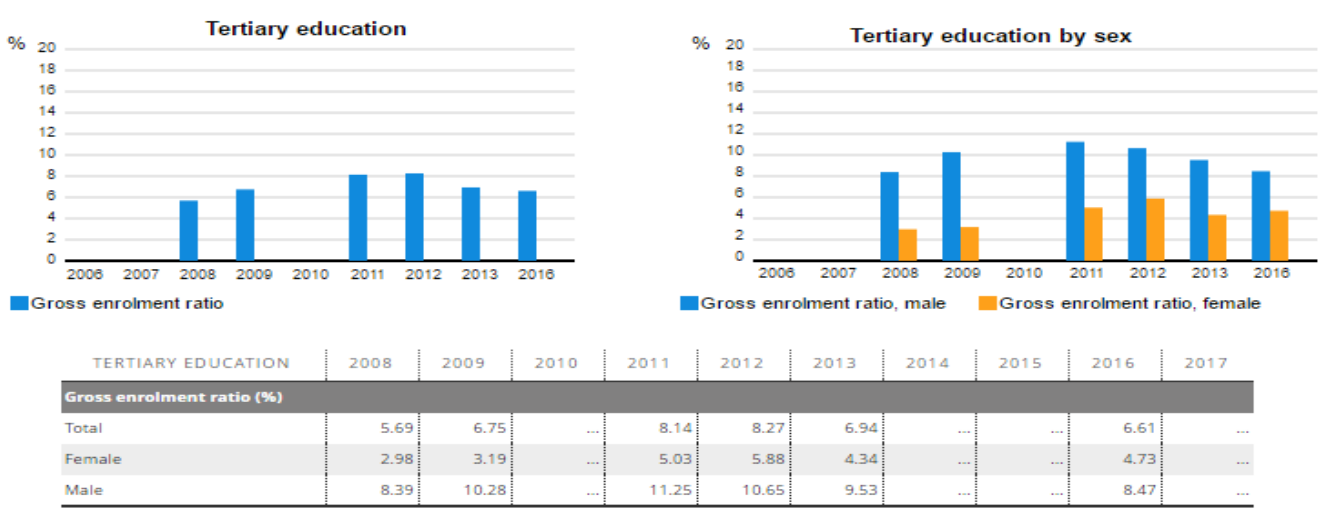

Source: Data from UNESCO Report, 2018

Figure 6. Gross enrollment in higher education

\section{Gender education in Urban and Rural areas}

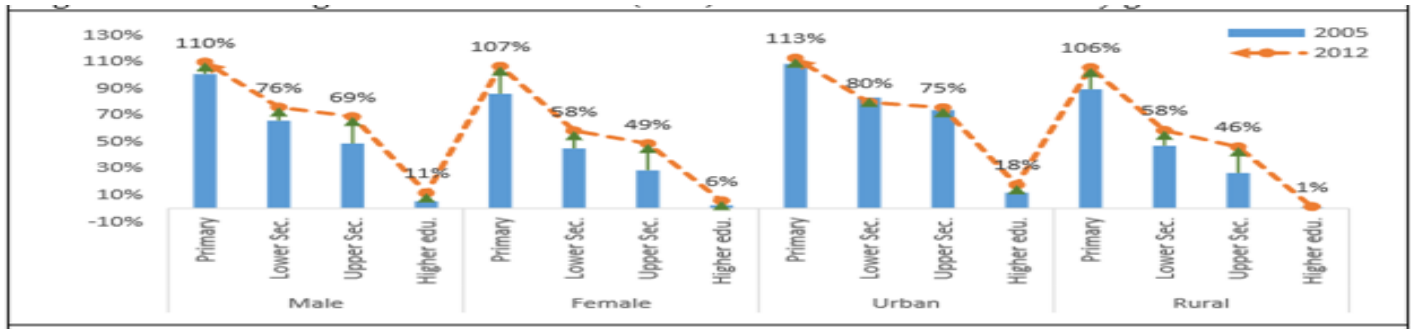

Source : MEPS-INC. (2014). «Rapport d'état du système éducatif — République Démocratique du Congo (RESEN RDC)». (Published by UNESCO-IIPE Pôle de Dakar). Retrieved from:

https://www.iipepoledakar.org/sites/default/files/fields/publication files/resen rdc _novembre_2014_0.pdf

Figure 7. Gross enrollment rates for all levels of education by gender and areas (20052012)

At the visualization of the figure 6 , the access to education sector for boys and girls in the DRC has shown consistent improvement in most of its national level education outcome indicators between 2005 and 2012. Consequently, the gender access to education as measured by gross enrollment ratios (GER) has also increased across all levels of education. But, despite the significant improvement in access to education, the DRC will fail to meet its 2015 MDG goals in education.

Furthermore, the figures 3 to 6 shown above are complementary to the figure 7 and explain more clearly, not only, the increase of national level of education sector; but also the needs of DRC' Government to implement the education sector for facilitating acquiring knowledge for all. 


\section{Recent data of gross enrollment rate in DRC (UNESCO Report, 2018)}

- Pre-primary level: The enrollment in pre-primary school=2.79\% (2018), with minimum $=0.86 \%$ (2001) and $\max =4.45 \%$ (2015) because of early or late school entrance and grade repetition;

- Primary level: The enrollment in primary school $=90.6 \%$ (2018) with $\min =53.39 \%$ (1999) and $\max 110.24 \%$ (2014). It can exceed $100 \%$ due to the inclusion of over-aged and under-aged student because of early or late entrance and grade repetition. In 2015 , there were 35,915 primary school= $10,572,422$ students and 46,000 out-of-school; the STR (number of pupils in PS/number of teacher in PS) $=38,37$ students per teachers, with $\min =26.02$ (1999) and $\max =44.75$ (1995); in 2014, number of pupils in $\mathrm{PS}=13.5$ million. Trained teachers in PS $=93.2 \%$ (2018) with $\min =89.85 \%$ (2015) and $\max =$ $96.02 \%$ (2007); ratio of female by male in PS $=0.75 \%$ (2018) with $\mathrm{min}=0.58 \%$ (1971) and $\max =0.99 \%$ (2015). Trained teachers are \% of PS teachers who have received the minimum organized teacher training (pre-service or inservice) required for teaching

- Secondary level: The enrollment in secondary school=27.21\% (2018), with $\min =9.56 \%$ (1971) and $\max =46.19 \%$ (2015). It can exceed $100 \%$ due to the same reason than primary school. In 2014, number of pupils in $\mathrm{SS}=4.4$ million; ratio of female by male in $\mathrm{SS}=0.45 \%$ (2018) with $\min =0.27 \%$ (1971) and $\max =0.64 \%$ (2015). There are 17,373 secondary schools $=3,484,459$ students $=1$ teacher to 100 pupils per class

- Higher education: The enrollment in tertiary school $=2.58 \%$ (2018) with $\min =0.66 \%(1971)$ and $\max =8.27 \%(2012)$. It is the number of students who have finished secondary school in the last 5 years. There are 31 recognized Congolese universities in DRC higher education.

\section{Gender participation summary}

During periods under analysis, the key access indicators showed that, overall, the DRC education has improved significantly between boys and girls in all levels of education, with especially focus on girls and in rural areas. Also, the significant improvement in the gross enrollment ratio reflect the policy focus on primary education, especially by international donors, in order to help the country achieve its MDG goals. But, despite the significant improvement in access to education, the DRC will fail to meet its MDG goals in education.

Notify that DR Congo has more than 15 million households, of which 11.7\% live in Kinshasa and $37.6 \%$ are urban. However, seven out of ten households are poor with a disparity between rural areas where about eight in 
ten households are poor and urban areas where fewer than seven out of ten households are poor. The average household size is 5 people. Unlike most subSaharan African countries, rural households are smaller than urban households (4.7\% vs. $5.4 \%)$. This average size hides large disparities, as a result of sociocultural, demographic and economic aspects (UNESCO, 2014).

\section{Management of Education sector}

\section{Education sector financing}

Despite recent efforts to improve budget allocation, the education sector in DRC is underfunded compared to most other countries in the region, with only 10.76 percent of the public budget being allocated to education and with education budget execution at about 1.8 percent of GDP. The SSA average is at 17 percent of overall budget allocation and 4.6 percent as a share of GDP. This places the DRC among the lowest countries of the SSA region.

The education sector remains largely financed by households. Although there has been some improvement regarding the burden borne by households, the latter still finance 73 percent of education spending in the DRC (down from 90 percent in 2005). The government contributes 23 percent to education spending (up from 6 percent in 2005), while donors contribute the remaining 4 percent. However, the reduction in the contribution of households tends to reflect the increase in the base education spending by the government rather than a reduction in the education burden itself on households.

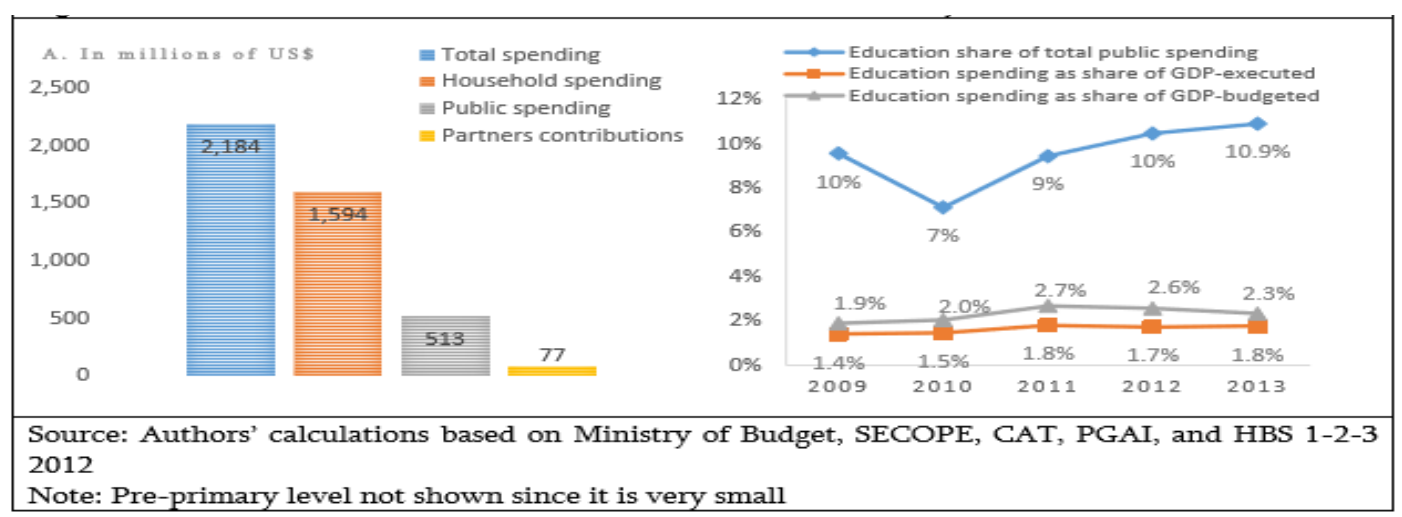

Figure 8. Sources of education sector finance and its breakdown by level of education, 2013 


\section{Budget allocation}

Budget allocation and execution are not aligned, resulting in large discrepancies between the two. In particular, while the budget execution of recurrent spending- which comprises mostly salary payments- is nearly fully executed, capital spending on the other hand is grossly under-executed (Figure E.9). In addition, the high share of salaries in recurrent spending indicates that the budget does not adequately provide for non-personnel costs which are essential for the public schools to efficiently teach, and manage their establishments. The low execution rate of capital spending, especially since 2010 , is linked to the budget's heavy reliance on external sources of funding for capital spending. In particular, the share of capital spending budgeted on external resources increased from 38 percent to 89 percent between 2009 and 2010 and has hovered between 84 and 89 percent since. However, the execution rate of these external funds has simultaneously decreased from 74 percent in 2009 to 22 percent in 2010 and to just about 3 percent in 2013 . One of the key reasons provided for the low execution rate of capital spending is that development partners require donor funded capital spending

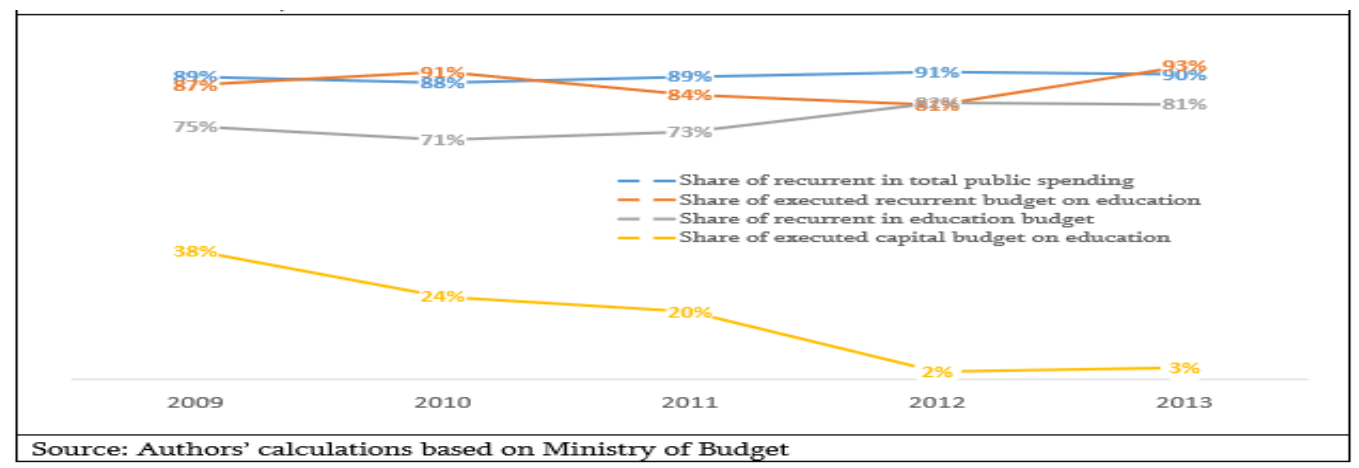

Figure 9. Trends of budget allocation and execution rates--total budget vs. personnel for the MEPSP and MESU, 2009-2013

\section{Education share of total public spending}

Education spending as share of GDP-executed Education spending as share of GDP-budgeted to be included into the budget but execution of these funds is not under the control of the government (Figure 9 and 10). Government's dependence on external funding in the budget preparation process clearly undermines the adequate provision of capital spending in the sector and leads to negative spillover effects on households where schools tend to demand contributions to compensate. 


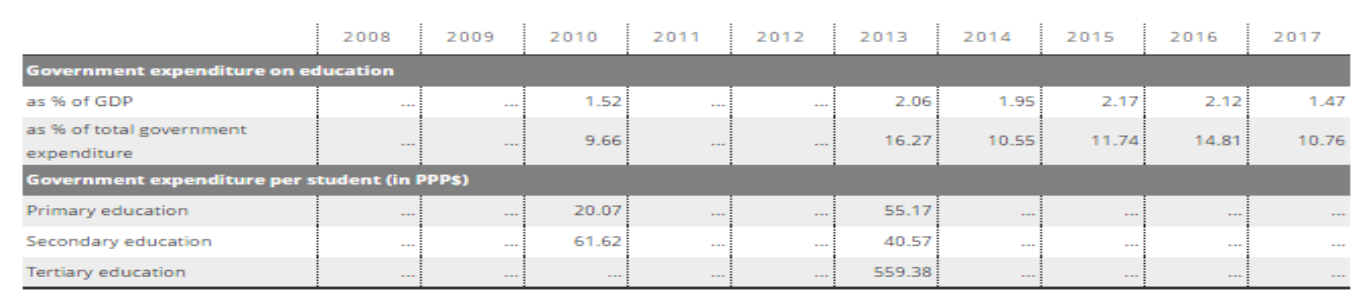

Source: UNESCO Report, 2018

Figure 10. Education expenditures

\section{Barriers to Gender education}

The country faces large internal inefficiencies in the education sector.

These are attributed to five main sources:

\section{a. School level}

- Inefficient student teacher ratio (STR) and class sizes: the STRs, with an average of $34: 1$ and 13:1, in both primary and secondary education are significantly below the optimal average levels of 40:1 and 25:1 respectively, which signals an under-utilization of resources

- High repetition and dropout rates: because of interruptions in schooling or repeating successive grade levels, children have difficulty in completing the desired school level within the standard timeframe and become overage students. Being overage in the classroom may be demotivating to the student as well, and also negatively impacts the teachers' ability to manage the class, given the wide age range.

- Unmanaged and unplanned staff onboarding into the education system: the growth in the number of teachers has outpaced the growth in student enrollment, especially in conventionné schools. Similarly, nonconventionné schools' share of non-salary spending constitutes about a third of total recurrent education spending compared with less than 2 percent for conventionné schools, which clearly reflects relatively inefficient use by such schools of the scarce resources

- Lack of professional teachers and a legion of uncertified teachers.

- Lack of classroom resources and teaching materials

- Lack of school infrastructure and classrooms

- Lack of job satisfaction

- Student issues

- Poor transportation system 

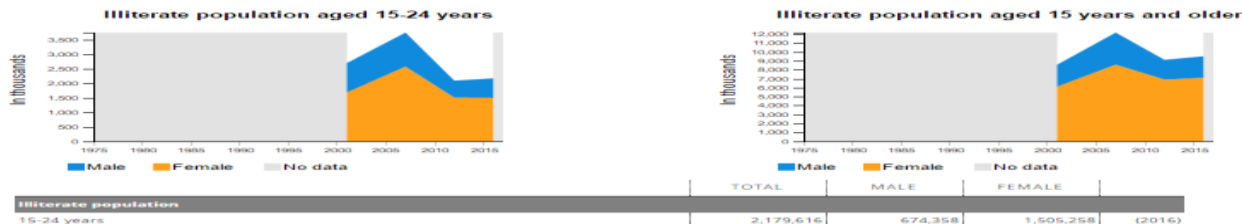

Source: UNESCO Report, 2016

Figure 11. Illiterate population

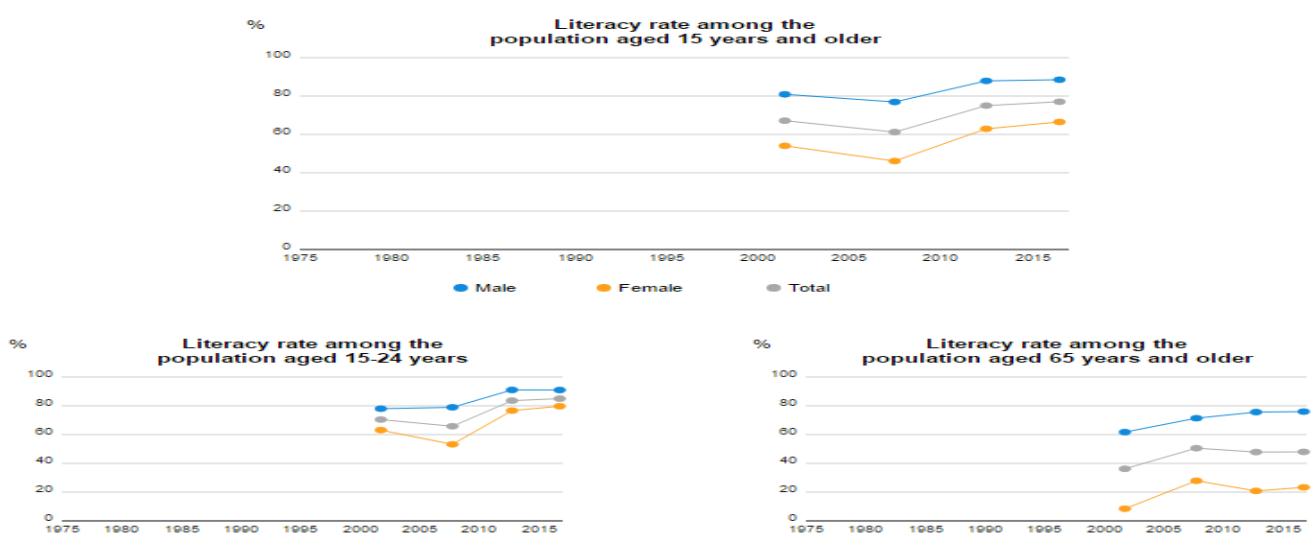

Source: UNESCO Report, 2016

Figure 12. Trends of Literacy rate

\begin{tabular}{|c|c|c|c|c|}
\hline & TOTAL & MALE & FEMALE & \\
\hline \multicolumn{5}{|l|}{ Literacy rate (56) } \\
\hline $15-24$ years & 84.99 & 90.96 & 79.71 & (2016) \\
\hline 15 years and older & 77.04 & 88.52 & 66.5 & (2016) \\
\hline 65 years and older & 47.97 & 75.96 : & 23.32 & (2016) \\
\hline
\end{tabular}

Source: UNESCO Report, 2016

Figure 13. Average data of literacy rate (2016) 


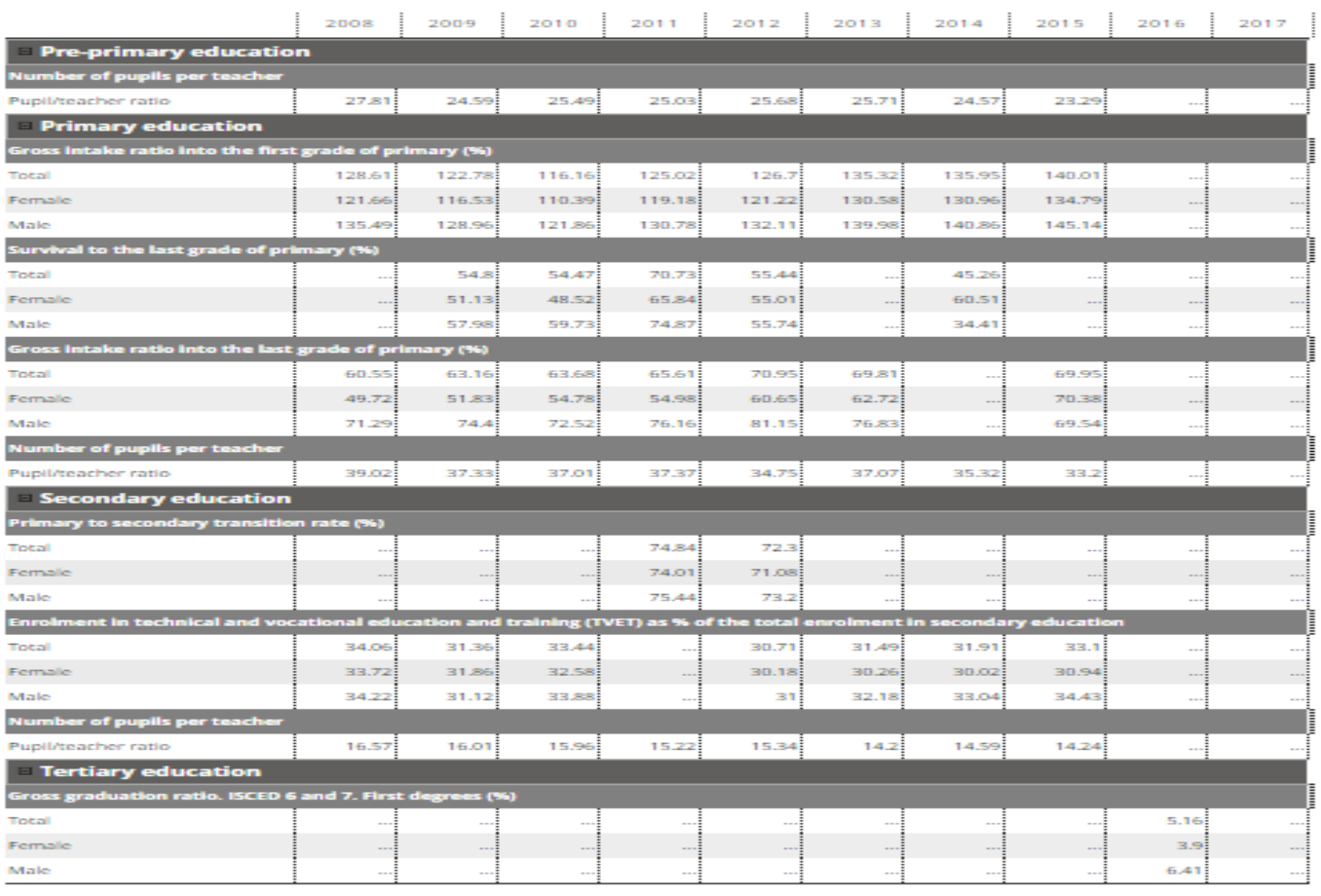

Source: UNESCO Report, 2018

b. Family

Figure 14. Overall data by levels of education

- Many family lack the means to help themselves

- Low productivity of the family workforce in the case of substance farming

\section{c. Social and political}

- Unequal distribution of income by social class

- No social protection policy: more than $70 \%$ of Congolese subsist on less than US $\$ 1$ a day= limited standard of living of the households

- Clientelism and nepotism

- Theft, misappropriation of funds, corruption, currency depreciation and hyperinflation, low wages

- Unstable environment, crisis and war

- Insecurity and violence at or around schools

- High poverty and unemployment level

- threatening social and political institutions with failure

- repeated political crises

- poor infrastructure

- an underdeveloped regulatory environment

- lack of institutional capacity

- weak rule of law fuel the country's persistent governance crisis

d. Economic

- Low coverage

- Poor financial performance

- Flee of government responsibility

- Misappropriation of funds provided by donors 
- Economic environment undeveloped

e. Gender

$\checkmark$ Male Barriers

- unlawful killings,

- disappearances,

- torture, rape, and arbitrary arrest and detention by security forces: Security forces continued to recruit and retain child soldiers and to compel forced labor by adults and children: delinquents, murderers, thieves, etc.

- societal discrimination against women and ethnic minorities,

- trafficking in persons, child labor,

- lack of protection for workers' rights,

- the difficulties of access to land, basic care and employment

Female barriers

- Violence against women seems to be perceived by large sectors of society to be normal

- Promotion of women's human rights and gender equality is not seen as a priority.

- Mass rapes, sexual violence and sexual slavery are used as a weapon of war by the Armed Forces of the Democratic Republic of the Congo and armed groups in the eastern part of the country: The eastern part of the country in particular has been described as the "rape capital of the world" and the prevalence of sexual violence there described as the worst in the world

- Female genital mutilation (FGM) is illegal and punishable by law with a penalty of two to five years of prison and a fine of 200,000 Congolese francs on any person who violates the "physical or functional integrity" of the genital organs

- Phenomenon of pendulum displacement: has developed, where people hasten at night to safety

- Unimaginable brutality in North and South Kivu: Armed groups attack local communities, loot, rape, kidnap women and children, and make them work as sexual slaves

- Women and girls abuses in several locations across the country and other areas away from the conflict zones by marauding militia

- Sexual violence and rape by state officials in Congolese prisons as punishment for politically active women

- High level of girls' dropout due to famine, misery, lack of means, abuses, etc.: lead consequently to early marriage, youth pregnancy, prostitution, death, etc. 


\section{DRC sector goals and priorities: Education sector strategy}

\section{Education and other linked domains policies: General background}

Steering the education sector in the right direction in order to address its most pressing needs and plan for its development requires a clear understanding of the issues at hand, their causes and the most effective ways to respond. This vision is outlined in the government's sector strategy as mentioned above.

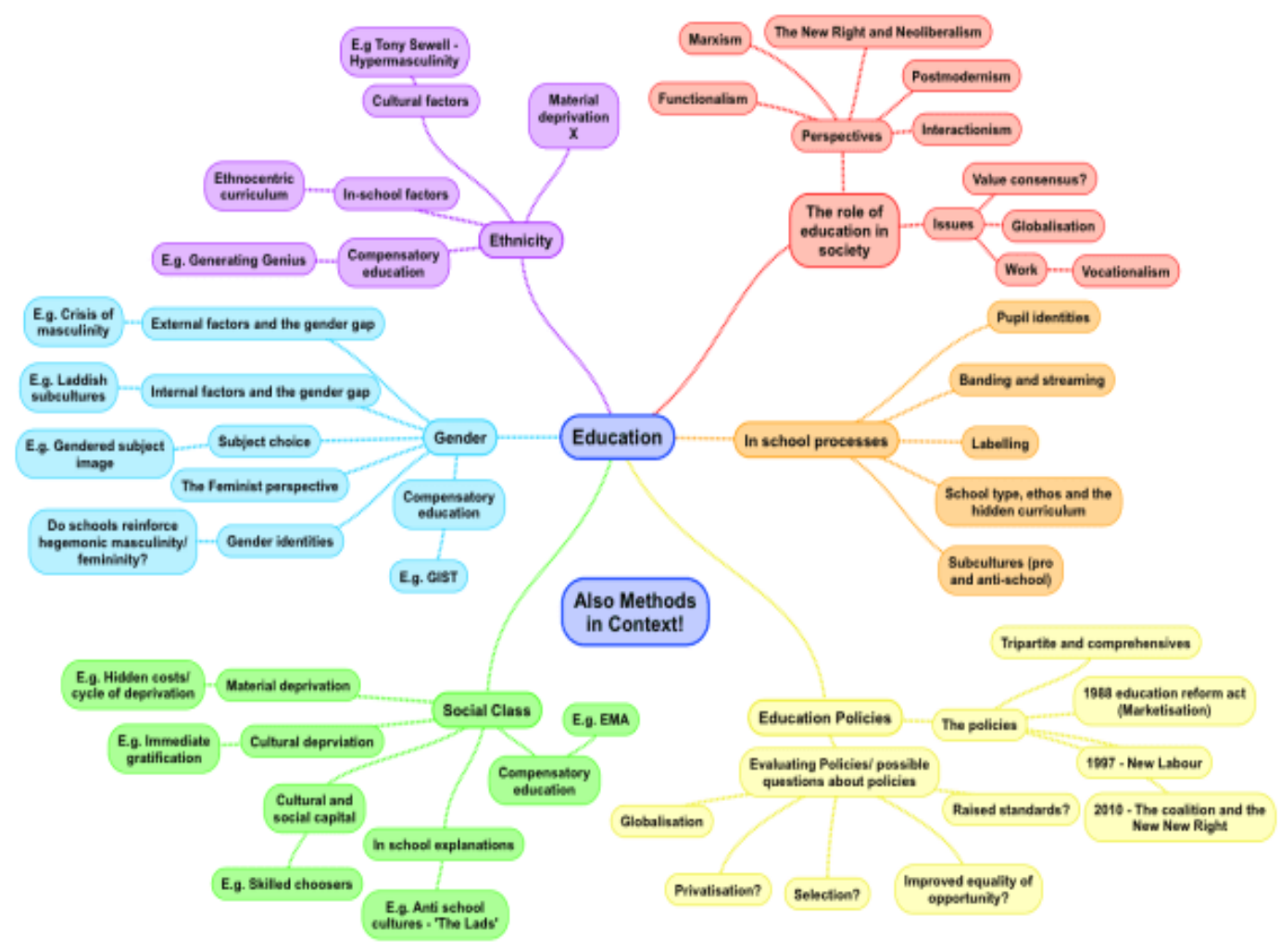

Source: Author' conception, 2018

Figure 15. Education policies background

\section{Governmental goals}

In its sub-sector plan, the Government, through its MEPSP, outlined three strategic objectives:

(i) improve access, affordability, equity and efficiency (ensure free primary education access and policy for all children, increase and rationalize school constructions, and extend registration policy and payroll inclusion of teachers, ensure the payment of operating expenses to all schools and administrative structure of their further support), 
(ii) improve quality of education and relevance of the educational program (production and distribution of learning materials), and

(iii) Strengthen governance capabilities (implement transparency of norms and mechanisms for managing resources and by improving management of all levels through more supportive and better organized partnerships).

\section{Education sector strategy}

(i) Pre-primary level: raise awareness of the benefits of pre-primary activities through community based early childhood centers and sensitization campaigns; increase participation in pre-primary education by improving the likelihood of on-time enrollment in primary, also increases preparedness for primary school, raising quality of the experience throughout the child's educational career; increase pre-school enrollment from 3 to 15 percent of children in 2015 .

(ii) Primary level: increase affordability of education by ensuring the State provides for all school fees and charges that are currently being paid for by households (frais de motivation and frais de fonctionnement being the two main ones); integrate of out-of-school children into the education system; support girls by increasing their chances of completion of primary education level.

(iii) Secondary level: make provision for construction of additional classrooms along with other key infrastructure such as toilets and equipment, facilities similar to the undertaking at the primary level; involve the reevaluation and revamping of the school curricula and programs to ensure coursework is up to date.

(iv) Tertiary level: allow for increased mobility of the workforce through a harmonized higher education certification process; allow Congolese 'licenciés' (graduates of an undergraduate program) to join the labor market; improve the curricula and school programs as well as an emphasis on adequate provision of laboratories and workshop space to carry out the practical part of the training; etc.

\section{Non-Governmental Organizations and donors goals}

Most of NGOs such USAID (United States Agency for International Development), UNICEF (United Nations Children's (Education) Fund, UNSECO (United Nations Educational Scientific and Cultural Organization), United Kingdom Department for International Development (DfID), etc. have jointly funded a groundbreaking to support the Government of the DRC's (GDRC) education program and training strategy. In 2015, they are committed to provide the country assistance to all levels of the education system and achieved 
impressive accomplishments in line with providing continuous technical advice and support to the Government of the DRC in its implementation of a three-year with at least $\$ 100$ million grant from the Global Partnership for Education to support the MOE's strategy.

This consists of increasing access, equity \& retention. In other words, it is about improving reading skills; allowing about 450,000 out-of-school children to improve retention in primary grade by 30 percent in target schools; employing professional development approaches for teachers that use local languages to help young children learn to read (consistent with the new curriculum); working at the provincial level to improve education governance and accountability; facilitating access to education in crisis environments of NGO's Education Strategy as well as the Mission's Country Development Cooperative Strategy (CDCS). Thus, all these implemented strategies do not only contribute significantly to the GDRC Mission objectives, but also increase equitable access to education in crisis, violence and conflict environments.

\section{DISCUSSION}

\section{Globalization and Gender education: overall balance for gender and education}

In this study, we define globalization as integration between countries, a phenomenon that increases trade of goods and services as well as bringing's people closer together. We try to capture some of the complexity of globalization by considering social, political and economic aspects of globalization. Social globalization concerns norms and cultural values, political globalization includes integration at a political level and economic globalization refers to trade of goods and services as well as investment flows across countries (Dreher, 2006).

The following findings represent the results of the study about impact of globalization on gender and education in the Democratic Republic of Congo. These are:

\section{Assessing gender equality and equity}

Gender equality doesn't mean we must have a 50:50 balance of men and women in every profession purely for the sake of equal representation. Given the existence of biological sex differences, it is reasonable for males and females to have different legal rights in some instances. Also, even in the absence of gender 
discrimination, we might always have fewer female firefighters simply because of such physical requirements.

In cases such as these, what is required is not equal treatment, but equitable treatment. Equity means recognizing that differences in ability mean that fairness often requires treating people differently so that they can achieve the same outcome. At times equity is necessary to achieve gender equality, but there are many instances where this is not the case.

But unfortunately, women and girls are at no inherent disadvantage due to a lack of ability that warrants differential treatment. Gender equality can often be achieved just by holding everyone to the same standard. The problem, as highlighted by the evidence reviewed above, is the irrational gender bias that women and girls are routinely subjected to.

Talking about inequality it is important to remember that comparing women to men is not just about justice and equality, it is also a question regarding development. Gender inequality in health, education and employment has been shown to affect the daily life of women and men as well as productivity and economic growth of a country negatively (Klasen and Lamanna, 2009; Potrafke, 2012). This question is therefore important for all countries and people, especially in the Democratic Republic of Congo. There are social and educational disadvantage between girls and boys. It means that for example:

- Although children are equally likely to be registered at birth irrespective of sex (around 70 per cent), girls are more likely to be developmentally on track at ages 3 and 4 than boys, while in the remaining countries there are no sex differences with regards to developmental status

- Gender disparities become more pronounced as children approach adolescence and puberty.

- Significant gender differentials persist in some domains and in certain countries, especially in GDP/economic development, employment and social development. Female are still considered as a weak being than men

- Suicide is the leading cause of death among adolescent girls aged 15-19 globally, with the highest rates seen in DRC (one in six deaths among adolescent girls).

- Homicide rates are not as high for girls as for boys, accounting for 30 per cent and 70 per cent of victims under age 20 , respectively.

- Worldwide, almost 750 million women and girls alive today were married before their 18th birthday. While there has been a decrease in child marriage globally, progress has not been equitable; high levels have persisted among the poorest while declines have been limited to the richest. 
- Globally, girls spend 550 million hours every day on household chores, 160 million more hours than boys their age spend. In some regions and countries, these numbers are twice as high.

\section{Gender gaps in enrollment}

The largest gender gaps in enrollment are in the poorest countries such as Africa, Middle East and South Asia which their gender gaps in enrollment are the widest.

- The enrollment rate is gradually low and low in all levels for girls than for boys, especially in heavily indebted countries

- Overall learning level are low for girls than for boys: girls do worse in calculations stream and boys in reading

- High levels of students learning as measured by their average performance and competencies on international assessment, girls still face gender inequality in academic performance and labor market: the male dominance in the extreme competency than girls

- Education lags most significantly among people who face multiple sources of disadvantage, not only income poverty, but also place of residence, disability and/or ethno-linguistic background. This means that there is:

$\checkmark$ High enrollment and completion in primary school

$\checkmark$ In secondary school, the number of student decreases due to numbers factors such as poor infrastructure, distance (most of school are located outside of their residence), poverty (parents lack means to provide their children furniture and school materials= uniforms, textbooks, etc.); they fail to afford transportation, ignorance, gender discrimination (some environments are not friend for girls students)

$\checkmark$ In higher education, the number of student is lower than previous levels

\section{Informal sector}

This sector represents both a significant component of gross domestic product and employment in most developing countries, and especially in DRC, it represents $80 \%$ of overall active population. But the female development still requires improvement in all country's level because of its larger costs assumed by women and its traditional understanding of women's role in society, due to:

- In social sectors:

$\checkmark$ Female are represented by the role of main providers of caring labor, inexpensive labor, unpaid labor at home, symbolic penalties, lack of 
recognition of their multiple qualities and hardships, the appropriation of their contributions with little or no remuneration, but also material disadvantages in their limited access to landed property, education, technology, and credit, etc.

$\checkmark$ Females are unable to advance because they relinquish their wages as a mean of supporting their family: Females from poor families feel obligated to helping with their household finances and often choose to work as a means of survival

$\checkmark$ Girls have to learn domestic responsibilities from their mothers and other roles performed: Female get married at an early age to repay debt

- In education and employment sectors:

$\checkmark$ Females are treated as subordinates to males within the family unit transcends throughout other institutions within society: Female are considered to be "short-term members of the family": parents did not waste time in schooling them.

$\checkmark$ Females who wanted to be independent and earning their own wages are subjected to unwanted sexual advances, violence, abuses, etc.

Thus, for many girls, further disadvantage based on disability, location, race, ethnicity or migration status compounds the challenges of building a fulfilling future. Sustainable change for girls and progress towards achieving the SDGs will require investments from governments, donors and development organizations, but also it requires engagement from communities, social networks, families and girls themselves. This includes prioritizing infrastructure, goods and services that address girls' vulnerabilities and remove barriers to their empowerment.

\section{CONCLUSION}

This study has analyzed the relationship between social, political, economic globalization and gender equality in welfare and work life. Concluding the results globalization seems to have a positive effect on female relative to male secondary and tertiary school enrollment, both testing overall as well as social, political and economic globalization. The effect on labor force participation seems to be positive both evaluating overall as well as social, political and economic globalization. In addition, the effect tends to be most robust testing the effect of social globalization. 
Globalization offers women unprecedented opportunities, but equally new and unique challenges. Gender inequality springs from many sources, and it is often difficult to determine which forms of inequality are being eliminated by the effects of globalization, and which are exacerbated. Work toward eliminating gender inequality in the framework provided by this study for Action has created awareness, monitoring, and alleviation of the externalities that the new global system creates for women.

Progress toward eliminating gender inequality in the future depends on finding and embracing the occasions, mostly in the political and legal realm, where the global approach strengthens women's security and welfare, and fighting the issues, mostly in the economic realm, where women are made worse off by the new global system.

Considering labor force participation in different sectors the results indicate that globalization has a negative effect on female relative to male labor force participation in the employment sector, significant both evaluating overall as well as social, political and economic globalization and excluding OECD countries.

Thus, according to these results, globalization overall has a significant positive effect both on gender equality in secondary and tertiary schooling as well as labor force participation. However, the effect in the employment sector is negative, decreasing gender equality. Further research is therefore needed to define a more robust relationship between the different aspects of globalization and gender equality in access to education, in welfare and work life.

\section{Conflict of Interest Statement}

I undersigned Madam Professor Doctor Sifa Bura Huguette that this document cannot be used without my permission, because being a personal work made available to the public to strengthen their intellect.

\section{REFERENCE}

Bussmann, M. (2009). The effect of trade openness on women's welfare and work life. World Development, 376), 1027-1038.

Dreher, Axel. "Does globalization affect growth? Evidence from a new index of globalization." Applied economics 38, no. 10 (2006): 1091-1110.

http://www.unicef.org/drcongo/french/Rapport_SITAN_RDC_2015 VF.pdf 
Klasen, S., \& Lamanna, F. (2009). The impact of gender inequality in education and employment on economic growth: new evidence for a panel of countries. Feminist economics, 15(3), 91-132.

MEPS-INC. (2015). "Annuaire statistique de l'enseignement primaire, secondaire et professionnel, année scolaire 2013-2014". Retrieved from: http://www.eduquepsp.cd/index.php/guides-etreferentiels/donneesstatistiques/annuaires-statistiques-2013-2014

Potrafke, N., \& Ursprung, H. W. (2012). Globalization and gender equality in the course of development. European Journal of Political Economy, 28(4), 399-413.

UNESCO. (2016). Global Education Monitoring Report - Unesco. May 28. https://en.unesco.org/gem-report/taxonomy/term/209

UNESCO. (2018). Global Education Monitoring Report - Unesco. May 28. https://en.unesco.org/gem-report/taxonomy/term/209

UNESCO. (2014). "Education: The Democratic Republic of Congo in the Spotlight." Press review, UNESCO, May 28. http://www.newsfromafrica.org/newsfromafrica /articles/art 14220.html. 